\title{
Influence of Weather on the Incidence and Spread of Aphid in Mustard (Brassica juncea L.)
}

\author{
Naresh Chand ${ }^{1}$, A.P. Dubey ${ }^{1}$, S.K Lodhi ${ }^{2}$, Thaneshwar ${ }^{3 *}$, \\ Jai Prakash ${ }^{3}$ and Sandeep Kumar
}

\author{
${ }^{1}$ Department of Agronomy, C.S.A.U.A. and T. Kanpur (Uttar Pradesh)-208002, India \\ ${ }^{2}$ Directorate of Extension, S.V.P.U.A. and T. Meerut (Uttar Pradesh)-250110, India \\ ${ }^{3}$ Department of Agronomy, S.V.P.U.A. and T. Meerut (Uttar Pradesh)-250110, India \\ ${ }^{4}$ Department of Soil Science, S.V.P.U.A.and T. Meerut (Uttar Pradesh)-250110, India \\ *Corresponding author
}

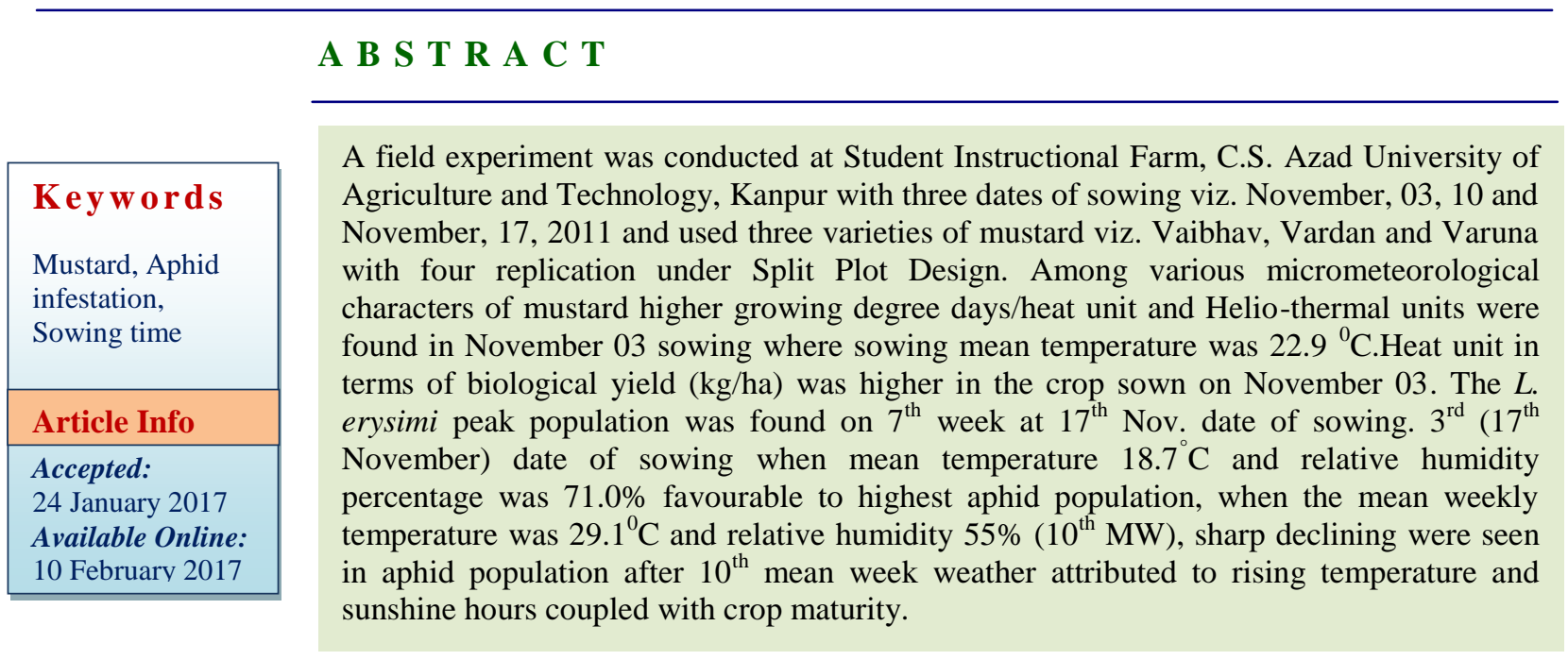

\section{Introduction}

Rapeseed mustard (Brassica Spp.) group of crops is the second most important oil seed crop of the country after groundnut contributing nearly $25-28 \%$ of total oil seeds production. Oil and fats are essential ingredients of balanced food and constituent of human body. These have medicinal and therapeutic value (Krishna Murthy and Bhatnagar, 1998). The oil seed scenario in the country has undergone a sea of change in the last fifteen years. India was importing edible oil and fats till mid 1980's; started exporting during the early 1990 's and thereafter status importing more than $40 \%$ of annual edible oil needs (Hundal et al., 2004).

Oilseed crop held a sizeable share of the country's gross cropped area (14\%) and contributed around $1.4 \%$ of the value of all agricultural commodities. Presently, India is playing a vital role in global demand spectrum of oilseed through accounting for about 12-13 per cent of world oilseed area, 67 per cent of world oilseed output, 6-7 per cent of world oil meal production, 5-6 per cent of world oil meal export, 6-7 per cent of 
world vegetable oil production, 15-17 per cent of world vegetable oil import and 10 per cent of the world edible oil consumption.

In India, it is mainly cultivated in Rajasthan, Uttar Pradesh, Madhya Pradesh, Bihar, Assam, Gujarat, Maharashtra, Haryana and West Bengal in varied situation. In Uttar Pradesh rapeseed mustard is grown in an area of 6.2 lakh hectare with the production of 0.73 million tones and the productivity is $11.58 \mathrm{q} / \mathrm{ha}$.. Rape seed mustard oil is used primarily for edible purpose and in the principal cooking oil in the mustard growing area of the country. Besides, seeds are used as condiments and in preparation of salad, juice curries and pickles. The meal cake left after oil extraction forms an important cattle feed and may also be as organic manure.

Inspite of fact that Indian mustard, plays such a prominent role in agriculture economy. It has very low yield. There are several factors responsible for low yield. The important ones are delayed sowing, inadequate fertilizer application and various biotic and abiotic stresses. There situation are further aggravated by the fact that mustard is cultivated on marginal and sub marginal lands and also predominantly as mixed crop under rainfed condition. The limited improvement in this crop has been mainly due to narrow genetic base arbitrary choice of parents without understanding their genetic architecture and combing ability.

During the past research efforts were made to evolve high yielding varieties to meet the growing demand of edible oil. Specially mustard oil which have been developed and oil seed production has also increased but due to growing demand of edible oil. There is a necessity the productivity of this crop at national level rapeseed and mustard covered 7.06 million hectare area and produced 4.7 million tonnes with productivity $1013 \mathrm{~kg}$ per hectare.
Agriculture production is most sensitive and vulnerable to climate change, as climate is the primary determinants of agriculture productivity is projected to decrease for the increase of local temperature $\left(1-2{ }^{0} \mathrm{C}\right)$ at lower latitudes, especially in seasonal dry and tropical/sub-tropical regions of the world (Anonymous, 2007).

Mustard is considerably sensitive to weather as evidenced from the variable response to different dates of sowing (Kumar et al., 1998; Kar and Chakravarty 2000; Yadav et al., 2007), one month delay in sowing from mid of October resulted losses of $40.6 \%$ in seed yield (Lallu, et al., 2010). The temperature is major factor that directly effects insect development, reproduction and survival. Although the behavior of individual insect may vary to global climate change (rise in temperature) the impact of global warming on plant insect interaction has been predicted to increase the intensity of herbivore pressure on plants (Dhaliwal, 2002).

In the flowering stage of Indian mustard coincides with period of increased temperature, then crop will be more susceptible to Aphids. Early sowing of crop during October $1^{\text {st }}$ week (15 days early than normal shown) is considered as one of the option to avoid aphid infestation during flowering stage. . Therefore, the present study was carried out to investigate on influence of weather on the incidence and spread of pest and disease in mustard (Brassica juncea L.).

\section{Materials and Methods}

The field experiment was conducted during rabi seasons of 2011-12 at Student's Instructional Farm of C.S. Azad University of Agriculture and Technology, Kanpur (U.P.). Geographically, Kanpur is situated in subtropical region. It is situated at an elevation of 125.9 meter above mean sea 
level, $26^{\circ} 20^{\prime \prime} 35^{\prime \prime}$ North latitude and $80^{\circ} 18^{\prime} 35^{\prime \prime}$ East longitude. The mean annual rainfall is about $868 \mathrm{~mm}$ mainly through south-west monsoon rains confined within June to last week of September with occasional frost and shower in winter season from North-East monsoon during December and January. During the experiment, the mean minimum and maximum temperature varied in between 4.1 to 15.9 and 18.0 to $32.1^{\circ} \mathrm{C}$, respectively.. As far as total amount of rainfall is concerned, $67.6 \mathrm{~mm}$ rains were recorded during whole growth period. The sunshine hours ranged from 0 to 9.3 hours during experiment. The crop received cumulative sunshine hours of about 109.5 hours during the experiment. Soil samples from a depth of $0-15 \mathrm{~cm}$ were collected from each plot of the experiment with the help of soil auger prior to fertilizer application and composite sample was drawn for determining its physical and chemical properties. The soil of experimental site was sandy loam in texture $(51.2 \%$ sand, $23.6 \%$ silt and $25.2 \%$ clay), low in organic carbon $(0.47 \%)$ and available nitrogen $(223 \mathrm{~kg} / \mathrm{ha})$, high in available phosphorus (12.6 kg/ha) and medium in available potassium $(155 \mathrm{~kg} / \mathrm{ha})$ with near to neutral $(7.70 \mathrm{pH})$ in reaction. The experiment was conducted in split plot design (SPD). Nine treatments combination comprised of three sowing date/sowing temperature viz. crop sown on November 03 at sowing mean temperature $22.9{ }^{\circ} \mathrm{C}$ (D1). Crop sown on November 10 at sowing mean temperature $21.8{ }^{\circ} \mathrm{C}$ (D2) and crop sown on November 17 at sowing temperature $21.8^{\circ} \mathrm{C}$ (D3) along with three varieties i.e. Vaibhav, Vardan, and Varuna ware used under present investigation keeping dates of sowing in main plots and variety of mustard in sub plots with 3 replications. The preparation of field by ploughing once with tractor drawn mould board plough, twice by cultivator which followed by planking. Each operation was followed by planking to have smooth clod free seed bed. After land preparation the layout of all the experiment was marked and sub-plots were demarcated within each main plot. Fertilizers were applied during last operation of field. The experimental crop was fertilized @ $120 \mathrm{~kg} \mathrm{~N} / \mathrm{ha}, 60 \mathrm{~kg} \mathrm{P}_{2} \mathrm{O}_{5} / \mathrm{ha}, 60$ $\mathrm{kg} \mathrm{K}_{2} \mathrm{O}$ and $25 \mathrm{~kg} \mathrm{~S} / \mathrm{ha}$ only half of the nitrogen was applied at the time of sowing while rest half amount of nitrogen was applied in two equal splits, each at optimum soil moisture after first irrigation and 60 days after sowing through urea and phosphorus and potash full doses were applied in deep furrows at the time of sowing. On next day after sowing, lay out was prepared with help of hand karha by separating the sub plots. Sowing was done date wise as treatment in row $45 \mathrm{~cm}$ apart using seed rate of $5 \mathrm{~kg} \mathrm{ha}^{-1}$. Later on plant spacing of $15 \mathrm{~cm}$ was maintained by thinning extra plants. Only manual one weeding and hoeing operation were done in the experimental first weeding was done with the help of khurpi after 15-20 days of sowing and second was done after crop after first irrigation at optimum moisture, to remove the weed and to provide aeration for plant rhizosphere for proper root development of experimental crop. Extra plants were uprooted periodically right from it attains complete emergence as to maintain uniform crop geometry and represented plant population. Two irrigation was given during the crop span, first irrigation after 30-35 days of sowing and second just before the flowering stage to harvest maximum potential yield. Plant protection measures were adopted against different insect-pests and diseases. It appeared the incidence off Alternaria blight, this disease is caused by fungus (Alternaria brassicae) affect all the aerial parts of the plant including the inflorescence and capsules. For the controle of this fungal disease spray Mancozeb-75 WP @ 2.0kg is 1000 liters o water per hectare at 10 days interval as soon as the symptoms start appearing on the plants. In the beginning mustard saw fly larvae became active caused 
on the leaves, it appears in the month of October and November. Mustard aphid is a very serious pest, both nymph and adult suck the sap of the tender leaves, twigs stem inflorescence and pods. For control of Aphids spray $0.05 \%$ malathion 50EC was twice during crop season. The aphid population per $10 \mathrm{~cm}$ of terminal shoot per plant were counted in each main and sub plots at meteorological week wise. It was summed up, averaged and correlated variety wise worked out infestation of aphid.

\section{Results and Discussion}

\section{Micrometeorological characters}

The various micrometeorological characters of mustard such as growing degree days/heat unit and heat use efficiency. Helio-thermal unit, and thermal use efficiency were affected during different sowing dates and sowing temperature.

\section{Growing degree days}

Growing degree days at different phenological stage were calculated by summation of daily mean temperature above base mean temperature $\left(4.5^{\circ} \mathrm{C}\right)$. As depicted in Table 1. the maximum heat units of $1623.60 \mathrm{~kg} / \mathrm{ha} /{ }^{0} \mathrm{C} /$ day from sowing to harvest were recorded by sowing in $3^{\text {rd }}$ Nov. 2011. Which is more as compared to progressive delayed sowing.

Heat use efficiency was more in 17 Nov. sowing as compare to 3 Nov. sowings. However, at emergence to bolting stage (0.08) highest heat use efficiency were recorded in $17^{\text {th }}$ Nov. sowing crop. Reason could be exploitation of climatic and soil moisture at important growth stages by the crop sown early and higher leaf area index which might have provided more photosynthetic area and contributed more dry matter. $17^{\text {th }}$ Nov. sowing crop attributed to higher heat use efficiency as compare to $3^{\text {rd }}$ Nov. sowing.

\section{Helio-thermal units}

The data depicted in Table 2. Indicate that helio-thermal unit available for the crop from its sowing to physiological maturity were higher for the crop sown during $3^{\text {rd }}$ November. This is true for all genotypes groups. This is because of the growth of the latter sown crops extended upto $2^{\text {nd }}$ week of March. Where in temperature increases in grain filling stages of delayed sowing crops subjected to bright sunny days.

The highest helio-thermal use efficiency was accumulated in Vaibhav variety as compared to Vardan and Varuna. The Vaibhav variety was grater reduction in yield of long season mustard variety under delayed sowing situations attributed to decrease in season length might have an effect by of reduction in their potential yield. While, inverse relationship between HTUE and grain yield of mustard was noticed with all the genotypes groups. It might be due to higher growing degree days and longer duration of day length during siliqua initiation to maturity stages. The similar results were also recorded by Hundal et al., (2004).

\section{Number of days}

\section{Date of sowing}

The evaluation of phasic development is the most important and aimed at assessment of the days to attain the performance of growth and yield are given in Table 3, 4 and 5 revealed that each successive delay of sowing days were found variable results in different sowing dates. The highest days 131 was recorded at $3^{\text {rd }}$ Nov. sowing as compared to $17^{\text {th }}$ Nov. sowings (125) which was attain 6 days lower from sowing to physiological 
maturity after 14 days successive delay in sowing by $3^{\text {rd }}$ November.

\section{Effect of Varieties}

The variety Varuna (129 days) have had more duration to complete there life cycle as compared to Vardan (126 days) and Vaibhav (128 days). Almost similar days were found in all the three varieties (Varuna, Vardan and Vaibhav) but Varuna have only three and one day more than Vaibhav and Vardan at maturity stage.

\section{Aphid population}

The influence of various environment parameters on the population build up of Aphid (L. erysimi) during 2011-12 is given in Table 1 . The result revealed that $L$. erysimi initiated its activity from third week of January in early (3, Nov. 2011) and mid (10
Nov. 2011) seeding date, while in late sowing (17 Nov. 2011) it was appear fourth meteorological week. When the crop was in flowering stage and hence the control measures have to be initiated before flowering. The population of mustard aphid increased gradually and reached its peak (269.26 aphids per $10 \mathrm{~cm}$ terminal shoot per plant) in the $7^{\text {th }}$ meteorological week of February (12-18 February) under late mustard crop, while, under early sown crop maximum aphid population (110.23 aphids per $10 \mathrm{~cm}$ terminal shoot per plant) was recorded during seventh standard meteorological week (12-18 February). It was observed that the pest incidence increased with an average weather parameters are maximum, minimum and mean temperature, relative humidity morning noon and mean, rainfall and B.S.S. range were $24.5,12.9$ and $18.7^{\circ} \mathrm{C}, 88,54 \%$ and $71 \%, 6.2$ and $4.6 \mathrm{hrs}$, respectively.

Table.1 Dry matter accumulation and heat use efficiency (kg/ha/0C/day) as influenced by date of sowing in mustard

\begin{tabular}{|c|c|c|c|c|c|c|c|c|c|}
\hline Crop growth & \multicolumn{3}{|c|}{ 3.11.2011 } & \multicolumn{3}{|c|}{ 10.11.2011 } & \multicolumn{3}{|c|}{ 17.11.2011 } \\
\hline & GDD & $\begin{array}{c}\text { Total } \\
\text { dry } \\
\text { mater }\end{array}$ & HUE & GDD & $\begin{array}{c}\text { Total } \\
\text { dry } \\
\text { mater }\end{array}$ & HUE & GDD & $\begin{array}{c}\text { Total } \\
\text { dry } \\
\text { mater }\end{array}$ & HUE \\
\hline $\begin{array}{l}\text { Emergence } \\
\text { to bolting }\end{array}$ & 669.20 & \multirow{4}{*}{9627} & 0.07 & 606.47 & \multirow{4}{*}{8841} & 0.07 & 608.03 & \multirow{4}{*}{7543} & 0.08 \\
\hline $\begin{array}{l}\text { Flowering } \\
\text { init. To } \\
\text { flowering }\end{array}$ & 844.97 & & 0.09 & 798.63 & & 0.09 & 796.07 & & 0.11 \\
\hline $\begin{array}{l}\text { Grain } \\
\text { development }\end{array}$ & 1264.97 & & 0.13 & 1227.17 & & 0.14 & 1219.00 & & 0.16 \\
\hline Maturity & 1623.60 & & 0.17 & 1556.47 & & 0.18 & 1481.17 & & 0.20 \\
\hline
\end{tabular}


Table.2 Yield response of helio-thermal units (HTU) and helio-thermal use efficiency $(\mathrm{kg} / \mathrm{ha} / 0 \mathrm{C} / \mathrm{hrs})$

\begin{tabular}{|c|c|c|c|c|}
\hline Date of sowing & Variety & $\begin{array}{c}\text { Grain yield } \\
(\mathbf{K g} / \mathbf{h a})\end{array}$ & HTU & $\begin{array}{c}\text { HTUE } \\
\mathbf{( k g / H T U})\end{array}$ \\
\hline \multirow{3}{*}{$\mathbf{D}_{\mathbf{1}}$} & $\mathbf{D}_{\mathbf{1}} \mathbf{V}_{\mathbf{1}}$ & 2003 & 8695 & 0.23 \\
\cline { 2 - 5 } & $\mathbf{D}_{\mathbf{2}} \mathbf{V}_{\mathbf{2}}$ & 2098 & 8695 & 0.24 \\
\cline { 2 - 5 } & $\mathbf{D}_{\mathbf{3}} \mathbf{V}_{\mathbf{3}}$ & 2218 & 8778 & 0.25 \\
\hline \multirow{3}{*}{$\mathbf{D}_{\mathbf{2}}$} & $\mathbf{D}_{\mathbf{1}} \mathbf{V}_{\mathbf{1}}$ & 1760 & 8516 & 0.21 \\
\cline { 2 - 5 } & $\mathbf{D}_{\mathbf{2}} \mathbf{V}_{\mathbf{2}}$ & 1800 & 8205 & 0.22 \\
\cline { 2 - 5 } & $\mathbf{D}_{\mathbf{3}} \mathbf{V}_{\mathbf{3}}$ & 1998 & 8700 & 0.23 \\
\hline \multirow{3}{*}{$\mathbf{D}_{\mathbf{3}}$} & $\mathbf{D}_{\mathbf{1}} \mathbf{V}_{\mathbf{1}}$ & 1520 & 8048 & 0.19 \\
\cline { 2 - 5 } & $\mathbf{D}_{\mathbf{2}} \mathbf{V}_{\mathbf{2}}$ & 1625 & 7891 & 0.21 \\
\cline { 2 - 5 } & $\mathbf{D}_{\mathbf{3}} \mathbf{V}_{\mathbf{3}}$ & 1805 & 8200 & 0.22 \\
\hline
\end{tabular}

Table.3 Days to attain during different phenological stages of mustard

\begin{tabular}{|c|c|c|c|c|c|c|c|c|}
\hline Treatment & Sowing & $\begin{array}{l}\text { Sowing to } \\
\text { Emergence }\end{array}$ & $\begin{array}{c}\text { Emerg. to } \\
\text { Bolting }\end{array}$ & $\begin{array}{l}\text { Bolting to } \\
\text { flowering } \\
\text { init. }\end{array}$ & $\begin{array}{c}50 \% \\
\text { Flowering }\end{array}$ & $\begin{array}{c}50 \% \\
\text { Flowering } \\
\text { to } \\
\text { Siliqua init. }\end{array}$ & $\begin{array}{c}\text { Siliqua to } \\
\text { Pod } \\
\text { development }\end{array}$ & $\begin{array}{l}\text { Pod dev. } \\
\text { To } \\
\text { Maturity }\end{array}$ \\
\hline $\mathrm{D}_{1} \mathrm{~V}_{1}$ & 03 Nov.11 & 08 Nov11 & 17 Dec. 11 & 29 Dec. 11 & 07 Jan.12 & 16 Jan. 12 & 19 Feb. 12 & 13 Mar. 12 \\
\hline $\mathrm{D}_{1} \mathrm{~V}_{2}$ & 03 Nov. 11 & 07 Nov 11 & 16 Dec. 11 & 26 Dec. 11 & 04 Jan.12 & 14 Jan.12 & 16 Feb. 12 & 11 Mar. 12 \\
\hline $\mathrm{D}_{1} \mathrm{~V}_{3}$ & 03 Nov. 11 & 08 Nov 11 & 17 Dec. 11 & 28Dec. 11 & 05Jan. 12 & 15 Jan. 12 & 19 Feb. 12 & 14 Mar. 12 \\
\hline $\mathrm{D}_{2} \mathrm{~V}_{1}$ & 10 Nov. 11 & 15 Nov 11 & 26 Dec. 11 & 06 Jan.12 & 15 Jan.12 & 25.Jan. 12 & 24 Feb. 12 & 17 Mar. 12 \\
\hline $\mathrm{D}_{2} \mathrm{~V}_{2}$ & 10 Nov. 11 & 15 Nov. 11 & 25Dec. 11 & 06Jan.12 & 14 Jan 12 & 23 Jan.12 & 22 Feb. 12 & 15 Mar. 12 \\
\hline $\mathrm{D}_{2} \mathrm{~V}_{3}$ & 10 Nov. 11 & 16 Nov.11 & 27 Dec. 11 & 07Jan.12 & 17 Jan. 12 & 26 Jan. 12 & 26. Feb. 12 & 18 Mar. 12 \\
\hline $\mathrm{D}_{3} \mathrm{~V}_{1}$ & 17 Nov. 11 & 23 Nov. 11 & 05Jan. 11 & 16Jan. 12 & 28 Jan. 12 & 06Feb. 12 & 06 Mar. 12 & 22 Mar. 12 \\
\hline $\mathrm{D}_{3} \mathrm{~V}_{2}$ & 17 Nov. 11 & 22 Nov. 11 & 04 Jan.11 & 15Jan.12 & 27Jan.12 & 05Feb. 12 & 03 Mar. 12 & 18 Mar. 12 \\
\hline $\mathrm{D}_{3} \mathrm{~V}_{3}$ & 17 Nov. 11 & 23Nov. 11 & 05 Jan.11 & 17Jan.12 & 28 Jan. 12 & 05Feb.12 & 06 Mar. 12 & 22 Mar. 12 \\
\hline
\end{tabular}


Table.4 Cumulative days to attain phenological stages

\begin{tabular}{|l|c|c|c|c|c|c|c|c|}
\hline Treatment & Sowing & $\begin{array}{c}\text { Sowing to } \\
\text { Emergence }\end{array}$ & $\begin{array}{c}\text { Emerg. } \\
\text { to } \\
\text { Bolting }\end{array}$ & $\begin{array}{c}\text { Bolting to } \\
\text { flowering } \\
\text { init. }\end{array}$ & $\begin{array}{c}\mathbf{5 0 \%} \\
\text { Flowering }\end{array}$ & $\begin{array}{c}\text { 50\% } \\
\text { Flowering to } \\
\text { Siliquae init. }\end{array}$ & $\begin{array}{c}\text { Siliquae to } \\
\text { Pod } \\
\text { development }\end{array}$ & $\begin{array}{c}\text { Pod dev. } \\
\text { To } \\
\text { Maturity }\end{array}$ \\
\hline $\mathrm{D}_{1} \mathrm{~V}_{1}$ & 03Nov.10 & 6 & 45 & 57 & 66 & 75 & 109 & 131 \\
\hline $\mathrm{D}_{1} \mathrm{~V}_{2}$ & 03Nov. 10 & 5 & 44 & 54 & 63 & 73 & 106 & 129 \\
\hline $\mathrm{D}_{1} \mathrm{~V}_{3}$ & 03Nov. 10 & 6 & 45 & 56 & 64 & 74 & 109 & 132 \\
\hline $\mathrm{D}_{2} \mathrm{~V}_{1}$ & 10 Nov. 10 & 6 & 47 & 58 & 67 & 77 & 107 & 128 \\
\hline $\mathrm{D}_{2} \mathrm{~V}_{2}$ & 10 Nov. 10 & 6 & 46 & 58 & 66 & 75 & 105 & 126 \\
\hline $\mathrm{D}_{2} \mathrm{~V}_{3}$ & 10 Nov. 10 & 7 & 48 & 59 & 69 & 78 & 109 & 129 \\
\hline $\mathrm{D}_{3} \mathrm{~V}_{1}$ & 17 Nov. 10 & 7 & 50 & 61 & 73 & 82 & 110 & 126 \\
\hline $\mathrm{D}_{3} \mathrm{~V}_{2}$ & 17 Nov. 10 & 6 & 49 & 60 & 72 & 81 & 107 & 122 \\
\hline $\mathrm{D}_{3} \mathrm{~V}_{3}$ & 17 Nov. 10 & 7 & 50 & 62 & 73 & 81 & 110 & 126 \\
\hline
\end{tabular}

Table.5 Phenophasic duration (Days)

\begin{tabular}{|c|c|c|c|c|c|c|c|c|}
\hline Treatment & Sowing & $\begin{array}{c}\text { Sowing to } \\
\text { Emergence }\end{array}$ & $\begin{array}{c}\text { Emerg. } \\
\text { to } \\
\text { Bolting }\end{array}$ & $\begin{array}{c}\text { Bolting } \\
\text { to } \\
\text { flowering } \\
\text { init. }\end{array}$ & $\begin{array}{c}\mathbf{5 0 \%} \\
\text { Flowering }\end{array}$ & $\begin{array}{c}\mathbf{5 0} \% \\
\text { Flowering to } \\
\text { Siliqua init. }\end{array}$ & $\begin{array}{c}\text { Siliqua to } \\
\text { Pod } \\
\text { development }\end{array}$ & $\begin{array}{c}\text { Pod dev. } \\
\text { To } \\
\text { Maturity }\end{array}$ \\
\hline $\mathbf{D}_{\mathbf{1}} \mathbf{V}_{\mathbf{1}}$ & 03 Nov.10 & 6 & 11 & 12 & 9 & 9 & 34 & 22 \\
\hline $\mathbf{D}_{\mathbf{1}} \mathbf{V}_{\mathbf{2}}$ & 03 Nov. 10 & 5 & 10 & 10 & 9 & 10 & 33 & 23 \\
\hline $\mathbf{D}_{\mathbf{1}} \mathbf{V}_{\mathbf{3}}$ & 03 Nov. 10 & 6 & 10 & 11 & 8 & 10 & 35 & 23 \\
\hline $\mathbf{D}_{\mathbf{2}} \mathbf{V}_{\mathbf{1}}$ & 10 Nov. 10 & 6 & 12 & 11 & 9 & 10 & 30 & 21 \\
\hline $\mathbf{D}_{\mathbf{2}} \mathbf{V}_{\mathbf{2}}$ & 10 Nov. 10 & 6 & 11 & 12 & 8 & 9 & 30 & 21 \\
\hline $\mathbf{D}_{\mathbf{2}} \mathbf{V}_{\mathbf{3}}$ & 10 Nov. 10 & 7 & 11 & 11 & 10 & 9 & 31 & 20 \\
\hline $\mathbf{D}_{\mathbf{3}} \mathbf{V}_{\mathbf{1}}$ & 17 Nov. 10 & 7 & 12 & 11 & 12 & 9 & 28 & 16 \\
\hline $\mathbf{D}_{\mathbf{3}} \mathbf{V}_{\mathbf{2}}$ & 17 Nov. 10 & 6 & 12 & 11 & 12 & 9 & 26 & 15 \\
\hline $\mathbf{D}_{\mathbf{3}} \mathbf{V}_{\mathbf{3}}$ & 17 Nov. 10 & 7 & 11 & 12 & 11 & 8 & & 29 \\
\hline
\end{tabular}


Table.6 Influence of weather parameters on aphid infestation in mustard varieties during crop growth period (Rabi, 2011-12)

\begin{tabular}{|c|c|c|c|c|c|c|c|c|c|c|c|}
\hline \multirow[t]{2}{*}{ SMW } & \multicolumn{3}{|c|}{$\begin{array}{c}\text { No. of aphid } \\
\text { population/10cm }\end{array}$} & \multicolumn{3}{|c|}{ Temperature ${ }^{0} \mathrm{C}$} & \multicolumn{3}{|c|}{$\begin{array}{c}\text { Relative humidity } \\
\%\end{array}$} & \multirow[t]{2}{*}{$\begin{array}{c}\text { Rainfall } \\
\mathbf{m m}\end{array}$} & \multirow[t]{2}{*}{$\begin{array}{c}\text { BSS } \\
\text { hr. }\end{array}$} \\
\hline & Vabhav & Vardhan & Varuna & Max. & Min. & Mean & $\mathbf{I}$ & II & Mean & & \\
\hline \multicolumn{12}{|c|}{ Timely sowing (03.11.2011) } \\
\hline 1 & 0.0 & 0.0 & 0.0 & 27.4 & 11.1 & 19.3 & 92.1 & 45.6 & 68.9 & 0.0 & 5.5 \\
\hline 2 & 0.0 & 0.0 & 0.0 & 17.7 & 5.1 & 11.4 & 94 & 58 & 76 & 0.0 & 2.1 \\
\hline 3 & 11.45 & 10.33 & 11.21 & 21.9 & 7.1 & 14.5 & 83 & 35 & 59 & 0.0 & 6.0 \\
\hline 4 & 26.30 & 24.56 & 20.39 & 24.0 & 8.5 & 16.25 & 85 & 45 & 65 & 0.0 & 7.2 \\
\hline 5 & 40.50 & 45.21 & 40.25 & 23.6 & 8.9 & 16.25 & 89 & 45 & 67 & 0.0 & 6.6 \\
\hline 6 & 60.58 & 65.58 & 63.69 & 26.4 & 11.4 & 18.9 & 90 & 41 & 65.5 & 0.0 & 7.9 \\
\hline 7 & 110.23 & 105.65 & 95.68 & 24.5 & 12.9 & 18.7 & 88 & 54 & 71 & 6.2 & 4.6 \\
\hline 8 & 85.24 & 75.28 & 60.98 & 25.0 & 10.4 & 17.7 & 90 & 45 & 67.5 & 0.0 & 6.8 \\
\hline 9 & 20.98 & 25.63 & 15.62 & 26.9 & 13.5 & 20.2 & 83 & 42 & 62.5 & 1.8 & 8.3 \\
\hline 10 & 0.0 & 0.0 & 0.0 & 29.1 & 14.9 & 22 & 73 & 37 & 55 & 0.0 & 8.9 \\
\hline 11 & 0.0 & 0.0 & 0.0 & 31.9 & 15.4 & 23.65 & 78 & 41 & 59.5 & 0.0 & 9.4 \\
\hline \multicolumn{12}{|c|}{ Mid sowing ( 10.11.2011) } \\
\hline 1 & 0.0 & 0.0 & 0.0 & 27.4 & 11.1 & 19.3 & 92.1 & 45.6 & 68.9 & 0.0 & 5.5 \\
\hline 2 & 0.0 & 0.0 & 0.0 & 17.7 & 5.1 & 11.4 & 94 & 58 & 76 & 0.0 & 2.1 \\
\hline 3 & 10.0 & 15.62 & 16.20 & 21.9 & 7.1 & 14.5 & 83 & 35 & 59 & 0.0 & 6.0 \\
\hline 4 & 35.62 & 32.65 & 34.58 & 24.0 & 8.5 & 16.25 & 85 & 45 & 65 & 0.0 & 7.2 \\
\hline 5 & 92.21 & 95.32 & 82.21 & 23.6 & 8.9 & 16.25 & 89 & 45 & 67 & 0.0 & 6.6 \\
\hline 6 & 121.32 & 138.65 & 100.36 & 26.4 & 11.4 & 18.9 & 90 & 41 & 65.5 & 0.0 & 7.9 \\
\hline 7 & 145.65 & 156.32 & 135.25 & 24.5 & 12.9 & 18.7 & 88 & 54 & 71 & 6.2 & 4.6 \\
\hline 8 & 155.28 & 154.28 & 115.0 & 25.0 & 10.4 & 17.7 & 90 & 45 & 67.5 & 0.0 & 6.8 \\
\hline 9 & 89.62 & 92.65 & 65.25 & 26.9 & 13.5 & 20.2 & 83 & 42 & 62.5 & 1.8 & 8.3 \\
\hline 10 & 18.65 & 35.36 & 12.25 & 29.1 & 14.9 & 22 & 73 & 37 & 55 & 0.0 & 8.9 \\
\hline 11 & 0.0 & 0.0 & 0.00 & 31.9 & 15.4 & 23.65 & 78 & 41 & 59.5 & 0.0 & 9.4 \\
\hline \multicolumn{12}{|c|}{ Late sowing (17.11.2011) } \\
\hline 1 & 0.0 & 0.0 & 0.0 & 27.4 & 11.1 & 19.3 & 92.1 & 45.6 & 68.9 & 0.0 & 5.5 \\
\hline 2 & 0.0 & 0.0 & 0.0 & 17.7 & 5.1 & 11.4 & 94 & 58 & 76 & 0.0 & 2.1 \\
\hline 3 & 0.0 & 0.0 & 0.0 & 21.9 & 7.1 & 14.5 & 83 & 35 & 59 & 0.0 & 6.0 \\
\hline 4 & 62.23 & 52.00 & 43.26 & 24.0 & 8.5 & 16.25 & 85 & 45 & 65 & 0.0 & 7.2 \\
\hline 5 & 92.2 & 85.69 & 60.59 & 23.6 & 8.9 & 16.25 & 89 & 45 & 67 & 0.0 & 6.6 \\
\hline 6 & 172.25 & 165.28 & 135.26 & 26.4 & 11.4 & 18.9 & 90 & 41 & 65.5 & 0.0 & 7.9 \\
\hline 7 & 269.26 & 250.26 & 201.25 & 24.5 & 12.9 & 18.7 & 88 & 54 & 71 & 6.2 & 4.6 \\
\hline 8 & 201.25 & 198.02 & 165.0 & 25.0 & 10.4 & 17.7 & 90 & 45 & 67.5 & 0.0 & 6.8 \\
\hline 9 & 115.98 & 80.62 & 70.0 & 26.9 & 13.5 & 20.2 & 83 & 42 & 62.5 & 1.8 & 8.3 \\
\hline 10 & 65.28 & 45.0 & 35.0 & 29.1 & 14.9 & 22 & 73 & 37 & 55 & 0.0 & 8.9 \\
\hline 11 & 10.63 & 8.0 & 5.0 & 31.9 & 15.4 & 23.65 & 78 & 41 & 59.5 & 0.0 & 9.4 \\
\hline 12 & 0.0 & 0.0 & 0.0 & 34.9 & 16.9 & 25.9 & 72 & 42 & 57.0 & 0.0 & 8.5 \\
\hline
\end{tabular}


While growth stage increased with decreased aphid population with increase in temperature and sunshine hr. decreased relative humidity from $8^{\text {th }}$ meteorological week $(19-25$ February) till the harvest of the crop. In present study the higher yield in first sown crop might be attributed to comparatively lower aphid population during crop growth and maximum time taken by the crop for its growth and development.

Among the varieties Vaibhav variety of mustard have more susceptible to number of aphid population than Vardan and lowest number of aphids per $10 \mathrm{~cm}$ terminal shoot/plant under Varuna in all the dates of sowing. Similar result were found earlier worker Mishra and Kanwat (2003), Roy and Baral (2002) and Roy and Chakravorty (2007).

In conclusion, higher growing degree days/heat unit and Helio-thermal units were found in November 03 sowing compared to November 17 sowing Heat unit in terms of biological yield $(\mathrm{kg} / \mathrm{ha}$ ) was higher in the crop sown on November 03. Weather parameter were found to have significant influence. The incidence of aphid population was found vary with different sowing dates. Aphid population was mostly influenced by mean temperature and relative humidity. The BSS (Bright Sun Shine) and evaporation did not have more influenced on aphid of mustard under the study. Among the varieties (Vaibhav, Vardan and Varuna) tested with different weather parameters were found better in explaining aphid population intensity. Based on the study it is calculated that $3^{\text {rd }}$ Nov. sowing date and variety Varuna proved beneficial for farmers and better option for realizing higher productivity of mustard in irrigated condition.

\section{References}

Anonymous. 2007. Climate change-impacts, adaption and vulnerability technical summary of working group II. to fourth assessment report Inter-governmental Panel on climate change. Parry, M.L.; Camziani, O.F., Paultik of, J.P. and Haon, C.E. (Eds.) Cambridge University Press, Cambridge, VF.K. pp. 23-78.

Dhaliwal, L.K. 2002. Crop weather aphid interaction in Raya (Brassica juncea L.)Under different hydrothermal environment. Ph.D. Dissertation, Punjab Agri. University, Ludhiana.

Hundal, S.S., Kaur, P. and Malikpuri. S.D.S. 2004. Radiation use efficiency of mustard cultivars under different sowing dates. J. Agromet., 6(1): 70-75.

Krishna Murtrhy, L., and Bhatnagar, V.B. 1998. Growth analysis of rainfed mustard (Brassica juncea L.). Crop Res., 15(1): 43-53.

Kumar, A., Singh, D.P., Yadev, Y.P. and Singh, B. 1998. Association between morphophysiological parameters and seed yield in Brassica genotypes. Cruciferae-Newslett., No. 20, 69-70.

Kar, G. and Chakravarty, N.V.K. 2000. Predicting crop growth and aphid incidence in Brassica under semi arid environmental. Indian J. Agric. CSU, 70: 3-7.

Lallu, Baghel, R.S., Srivastava, S.B.L. 2010. Assessment of mustard genotypes thermo-tolerance at seed development stage, Indian J. Plant Physiol., 15(1): 36-43.

Mishra, S.K. and Kanwat, P.M. 2003. Impact of temperature and humidity on the population dynamics of Liphiserysimi Kalt on mustard in semi-arid region of Eastarn Rajasthan. Annals of Agri. Res., 24(3): 645-648.

Ray, S.K. and Baral, K. 2002. Role of weather parameters on population build up of mustard aphid (Kaltenbach). $J$. Oilseeeds Res., 19: 86-89. 
Roy, Sumana and Chakravarty, N.V.K. 2007. Phenological development and biomass partitioning in Brassica as influenced by weather conditions. $J$. Agrometeorol., 9(2): 216-222.

Yadav, P.N., Uttam, S.K., Singh, R.P. and
Kaushal Kuma. 1996. Effect of fertilizer and moisture conservation on productivity, economics and water use efficiency (Brassica juncea L.). Curr. Adv. Agri. Sci., 3(2): 108-111. 8 ref

\section{How to cite this article:}

Naresh Chand, A.P. Dubey, S.K Lodhi, Thaneshwar, Jai Prakash and Sandeep Kumar. 2017. Influence of Weather on the Incidence and Spread of Aphid in Mustard (Brassica juncea L.). Int.J.Curr.Microbiol.App.Sci. 6(2): 1655-1664. doi: http://dx.doi.org/10.20546/ijcmas.2017.602.185 